\title{
Eksemplarisk strejke. Pirelliarbejdernes kamp
}

I langt mere end et år har arbejderne ved Pirelli-værkerne ført kamp. Pirelli har ikke kun det italienske monopol på bildæk; det er på samme tid en vertikal trust, hvis fabrikker producerer alt, som på en eller anden måde har med gummiindustrien at gøre. De to vigtigste virksomheder - i Settimo ved Torino og »Biocca« i Milano - beskæftiger mere end 20.000 arbejdere. Omsætningen overstiger 200 mia. Lire. Kampen ved Pirelli har kun forbigående antaget form af frontalt sammenstød. Den blev ført sådan, at den kunne vare længst muligt, uden at arbejderne derved mistede deres samlede løn, og at den på trods af dette tilføjede arbejdsgiveren størst muligt tab. Den lignede en minikrig, hvis successive afsnit tillod, at der skabtes enhed i basis, direkte demokratiske former, at kampens niveau såvel som metoder kunne hæves, tillige med at arbejdernes selvorganisering forbedredes. På kampens højdepunkt mellem oktober og slutningen af december 1968 - anvendte arbejderne ved fabrikken i Settimo en hidtil ukendt form for kamp. Den blev udarbejdet i basis, og som en forløber for arbejderkontrol over produktionsprocessen, hvis ikke den ligefrem kan siges at være arbejdernes tekniske selvforvaltning af virksomheden: Selvbestemmelse over produktet gennem udarbejdelse af »mod-normer«. 


\section{En smule historie}

Februar 1968: Fagforeningerne hos Pirelli afslutter en branche-tarifoverenskomst, som hovedsagelig vedrører grundlønnen. Basis er ikke tilfreds med overenskomsten. Men virksomhedsledelsen vægrer sig mod at forhandle om arbejdstempo og akkord. Det stærkeste fagforbund CGIL har heller ikke lagt særlig megen vægt på disse fordringer, fordi det mente, at medlemmerne endnu ikke var klar til at kæmpe for disse krav, og at de andre fagforeninger ikke ville være med.

Februar til juni 1968: Et mindretal begynder alligevel agitation for disse krav. For ikke at bryde med de andre fagforeninger, og for hverken at ødelægge forholdet til de uorganiserede eller aktivisterne, opmuntrer CGIL til dannelsen af enhedskomiteer i værkstederne (med deltagelse af de andre fagforeninger). Igennem en række diskussioner opstilles der til slut en særdeles detaljeret liste over kravene. CGIL udsteder parolen: »Diskuter med alle kollegerne i afdelingerne; gå over til aktion (to timers strejke pr. arbejdsgruppe) når mindst $80 \%$ af arbejderne i en afdeling er overbevist.«

Juli til oktober 1968: Fra juli greb arbejdsnedlæggelserne på de fleste værksteder om sig. Stadig nye møder finder sted inden- og udenfor virksomhederne. I Milano mødes arbejderne og studenterne, som blandt andet foreslår »strejke om akkorden«. Derpå dannes »basiskomiteer « på fabrikken; de truer fagforeningshierarkiet. Den avis der udgives af den kommunistiske virksomhedsgruppe i Bicocca kritiserer ganske vist studenternes forsøg på at sabotere fagforeninerne og skabe en parallel kamporganisation. Den skriver imidlertid: »man må være enig med dem, der opmuntrer basis' mod på at overvinde den bureaukratiske træghed ...

Og nogle måneder senere: »Udviklingen af demokratiet inden for fagforeningerne har spillet en betydelig rolle for kampens fremgang.«

Oktober til december 1968: Som følge af den bevægelse, der først startede i oktober i Torino bestemmer arbejderne selv produktionshastigheden og organiserer deres arbejde selv. De sætter virksomhedshierarkiet ud af spil. Til denne nye form for kamp kommer korte arbejdsnedlæggelser og møder. I begyndelsen af december svarer Milano-arbejderne på en 24-timers lock-out med en demonstration. som studenterne tilslutter sig, og som lammer bycentret.

21. december 1968: Underskrivelse af tarifoverenskomsten, som forinden var blevet godkendt på et møde med 15.000 arbejdere i Torino og Milano. De vigtigste bestemmelser er:

Dannelsen af den »kommission for produktionstempo«, som skaffer sig selv viden om den måde, normeringerne og akkordlønnen bliver bestemt på, og som så kan forlange en revision heraf, hver gang arbejdsforholdene ændres f.eks. ved indførelse af ny teknik. Dannelsen af en »kontrolkommission «, som skal sikre, at de produktionsnormer, der blev accepteret, overholdes af virksomhedsledelsen.

En forhøjelse af akkordlønnen på 32 lire i timen.

Fra nr. 24 af »Les Temps Modernes«. Paris.

\section{Akkordstrejken}

Målet for det, der foregår, kan synes enkelt: Det drejer sig om at bringe såvel produktionstempoet (d.v.s. det antal operationer, arbejderen skal udføre for at producere et bestemt antal stk. på en bestemt tid) som den af virksomhedsledelsen påtvungne akkordløn på bane som problem. I praksis kræver det rigtignok en kraftpræstation i selvorganisation og teknisk kunnen samlet at sinke gangen i en kompleks storvirksomhed. Lige så lidt, som hjulene i et urværk drejer sig med samme hastighed, lige så lidt er arbejdsrytmen og arbejdstempoet det samme i en stor fabriks forskellige afdelinger. For at det kan gå uden vanskeligheder, bliver alle arbejdsprocesser jævnligt nøje fastlagt på sekunder gennem et teknisk hierarki, der lige fra tidsstudiefolk til mestrene sørger for, at alle arbejdsprocesser udføres på de i forvejen fastlagte tider.

Sidste august opdagede arbejderne i Settimo efter måneders resultatløs kamp, at de kunne vende det akkordlønssystem, som man havde påtvunget dem, mod Pirelli som en boomerang. Faktisk havde akkordlønnen, som engang udgjorde en temmelig stor del af den samlede løn, i praksis været blokeret i årevis. Direktionen vægrede sig mod at forhandle om den. Den ville efter behag kunne bestemme arbejds- 
tempoet og intensiteten på hver arbejdsplads. I modsætning hertil var grundlønnen, til hvilken akkordlønnen føjes, blevet forhøjet i fag- og virksomhedstarifoverenskomsten.

Når det altså lykkedes arbejderne at sinke gangen i hele fabrikken, kunne de tilføje Pirelli et forholdsvis meget større tab, end de selv ville komme til at lide ved at akkordpræmien faldt bort (ca. 12\% af den samlede løn).

Som på andre storvirksomheder ligger $\mathrm{Pi}$ rellis driftsledelses magt $\mathrm{i}$ det forhold, at det er umuligt for arbejderne at komme virkelig i forbindelse med hinanden, $i$ at de er isolerede fra deres maskine og isolerede i deres afdelinger og i fagbevægelsens splittelse. Alle arbejderne har de samme bekymringer, men da de ikke alle kan tale sammen om det, må de give disse bekymringer luft i ukontrollerede, korte og resultatløse raseriudbrud.

Arbejderne fra Settimo vidste af erfaring, at direktionens indrømmelser og løfter ikke gav dem meget. Man gav dem med den ene hånd 30/100 lire i akkordpræmier, men tog med den anden 50 fra dem ved den næste lejlighed. Man lod som om man ville sænke arbejdstempoet, men man påtvang dem lidt efter lidt (eller i anledning af en teknisk ændring) igen en akkurat lige så uudholdelig arbejdsintensitet.

Løfter og indrømmelser var altså ikke godt for noget. Tværtimod var det nødvendigt at fastsætte et acceptablet arbejdstempo og arbejdsnormer såvel som en stadig kontrol fra arbejdernes side over anvendelse af disse arbejdsnormer og dette arbejdstempo gennem fagforeningsmæssige ad-hoc-kommissioner. Men hvorledes skulle man gennemføre denne arbejderkontrol? Gennem strejke? Det var helt utænkeligt. Med en strejke på 24 eller 48 timer ville virksomhedsledelsen ikke kunne tvinges til indrømmelse. Den ubegrænsede strejke? Det ville næppe være bedre. Når en virksomheds hele indre orden står på spil, foretrækker en industrigigant i almindelighed at holde ud i uger, ja måneder, med det mål at udhungre og så splitte arbejderne, idet man tilbyder dem nogle smuler.

Nej, kontrollen kunne kun gennemføres på én eneste måde: Man anvendte den, idet man gennem praksis afdækkede de hemmeligheder i arbejdsorganisationen, som virksomhedshierarkiet omhyggeligt dækkede over. Hvorledes fastlægger man tidsenhederne for udførelsen af bestemte arbejdsprocesser? Efter hvilke kriterier fastlægger man tiderne for hvilepauser? Hvor meget må man forhøje den absolut nødvendige tid til en opgave, når man skal tage hensyn til, at man ikke kan holde den samme rytme 8 timer i træk som man kan i 20 minutter?

Arbejderne fra Settimo måtte kende svaret på disse og mange andre spørgsmål. De måtte overvinde splittelsen i fagbevægelsen og stole på hver enkelt blandt 1.000 arbejderes solidaritetsfølelse og klassebevidsthed. Gennem initiativer på arbejdspladsen måtte de udarbejde nye produktionsnormer og regulere arbejdsgangen $i$ alle afdelingerne uden virksomhedens tekniske apparat, ja, imod dette.

For at komme så vidt gik de frem på følgende måde: Hver arbejder ved en maskine fastlagde arbejdstempoet på eget initiativ og i overensstemmelse med sine arbejdskammerater. De nye normer blev skrevet på kort, som man døbte "mod-normer«, og som blev hængt op ved hver maskine på det sted, som var beregnet til virksomhedsledelsens funtionstabel. Koordinationen af arbejdstempoet mellem de enkelte afdelinger skabtes ved »indkøring« og succesive rettelser.

Arbejdstempoet blev i øvrigt forandret alt efter kampens stadium. Kampen varede to måneder på denne måde. Da det drejede sig om at give virksomhedsledelsen en lektie, der kunne huskes særlig godt, lod arbejderne endog produktionen falde til 30\% af gennemsnittet. De tilføjede således Pirelli et tab på 70\%, men tabte selv kun ca. 10.000 lire om måneden (af en månedlig gennemsnitsfortjeneste på 80. til 90.000 lire).

Denne kampmåde forudsatte naturligvis en følelse af solidaritet og engagement, som kun selvorganisationen og basisdemokrati kunne frembringe. Forudsætningerne for successen var, at man tydeligt kunne se den demokratiske forbindelse mellem arbejderne og deres komiteer, deres delegerede og deres fagforeningsorganisation.

Pirelli forstod ikke tidsnok, at den fagforeningsmæssige enhed stabiliseredes under det uimodståelige pres fra basis, hvor de uorganiserede ikke nødvendigvis var de mindst aktive. Han troede, han kunne splitte arbejderne ved at tilbyde dem 9 lire mere i timen. Dette forslag fremkaldte kun arbejdernes vrede. Han måtte til sidst indrømme dem en forhøjelse på 32 lire, 
altså meget mere end de 20 lire, som generelt blev tilbudt den øvrige industri de sidste måneder. Han truede arbejderne med at trække tre timer fra arbejdstiden, lukkede dem ude fra fabrikken i Milano i 24 timer, men blev igen tvunget til tilbagetog gennem en ny sænkning af arbejdstempoet. Ufrivilligt fremmede han endog udbredelsen af denne kampform til andre af koncernens virksomheder, f.eks. Biocca. Og denne eksemplariske kamp var årsag til, at en ny form for militante fagforeninger opstod.

Den feber, der opstod ved deltagelse i kampen, greb også dem, der indtil da havde holdt sig uden for enhver bevægelse. En ny kritisk bevidsthed udviklede sig. Denne er typisk for den nye generation af arbejdere, som ikke finder sig i nogen autoritær eller faderlig holdning. (forkortet).

Fra udgaven af 20. 12. 1968. »Rinascita«, Rom.

\section{Bevagelseskrigen}

I marts/april 1969 fortsatte Pirelli-arbejdernes kamp. Deres hovedkrav er 40-timers uge med fri lørdag og søndag, dertil kommer krav, som angår arbejdsforholdene og arbejdsorganisationen.

Pirelli har som enhver anden arbejdsgiver sin egen »tekno-struktur « inden for virksomheden. I dag behøver fagforeningen på denne måde mere end nogen sinde sin egen struktur inden for virksomheden. Der gøres erfaringer: kontrolkommissioner, afdelingskomiteer, møder. Tilskyndelser fra basis mangler bestemt ikke. I dag er det mere nødvendigt end nogen sinde at styrke arbejdernes fagforening, at forbinde demokrati og deltagelse med koordinationen, at lade den faglige enhed forneden forene sig med den splittede fagbevægelse - med gennemdiskuterede, præcist fastlagte mål, for hvilke man kæmper med sammenhold og disciplin. I dag håber Pirelli og udfordrer påny. Arbejderne har imidlertid allerede svaret med imponerende kraft og enighed. Denne kraft må ikke gå tabt, da den afværger de bureaukratiskautoritære arbejdsmetoder i fagforeningen og styrker viljen til deltagelse og selvkontrol. Pirelli er bange for denne udvikling. Et medlem af bedriftsrådet i Settimo sagde: »Arbejderne har tilegnet sig fagforeningens forslag om selv at føre kampen, træffe afgørelser om nye kampformer på møder, og udarbejde egnede organisationsformer. Arbejdsgivernes gamle plan om at have en fordummet arbejderklasse, som er ude af stand til at tænke, er blevet tilintetgjort.«

Uddrag fra nr. 158/69 »rassegna sindacale« Rom.

Oversat fra tysk af Karin Borg og Ilja Wechselmann 